\title{
Effects of Biochar Application on Soil Properties, Plant Biomass Production, and Soil Greenhouse Gas Emissions: A Mini-Review
}

\author{
Dafeng Hui ${ }^{\circ}$ \\ Department of Biological Sciences, Tennessee State University, Nashville, USA \\ Email:dhui@tnstate.edu
}

How to cite this paper: Hui, D.F. (2021) Effects of Biochar Application on Soil Properties, Plant Biomass Production, and Soil Greenhouse Gas Emissions: A Mini-Review. Agricultural Sciences, 12, 213-236. https://doi.org/10.4236/as.2021.123014

Received: October 11, 2020

Accepted: March 9, 2021

Published: March 12, 2021

Copyright $\odot 2021$ by author(s) and Scientific Research Publishing Inc. This work is licensed under the Creative Commons Attribution International License (CC BY 4.0).

http://creativecommons.org/licenses/by/4.0/

\begin{abstract}
Biochar has been applied extensively as a soil amendment over the past decades. This review summarizes the general findings of the impacts of biochar application on different aspects from soil physical, chemical, and microbial properties, to soil nutrient availabilities, plant growth, biomass production and yield, greenhouse gases (GHG) emissions, and soil carbon sequestration. Due to different biochar pyrolysis conditions, feedstock types, biochar application rates and methods, and potential interactions with other factors such as plant species and soil nutrient conditions, results from those studies are not inclusive. However, most studies reported positive effects of biochar application on soil physical and chemical properties, soil microbial activities, plant biomass and yield, and potential reductions of soil GHG emissions. A framework of biochar impacts is summarized, and possible mechanisms are discussed. Further research of biochar application in agriculture is called to verify the proposed mechanisms involved in biochar-soil-microbial-plant interactions for soil carbon sequestration and crop biomass and yield improvements.
\end{abstract}

\section{Keywords}

Biochar, Soil, Plant, Microbe, Nutrient, Biomass, Yield,

Greenhouse Gas Emission, Carbon Sequestration

\section{Introduction}

Biochar is a charcoal-like material that produced from pyrolysis of biomass at high-temperature with limited or no-supply of oxygen [1] [2] [3] [4] [5]. It can be derived from a wide range of raw materials such as organic waste, feedstock 
like wood chips, crop residues, animal manure, sewage sludge, and microalgae biomass [6] [7] [8]. Biochar is mainly composed of stable and recalcitrant organic carbon (C) and can be used as a soil amendment [9] [10].

The physical and chemical properties of biochar depend on pyrolysis conditions such as temperature and the feedstock type [11] [12]. Biochar has a high surface area and porous carbonaceous structure [13] [14], thus has a strong affinity to inorganic ions such as nitrate and phosphate [15]. Since it contains highly condensed aromatic structures, biochar is difficult to be decomposed in soil and can sequestrate a portion of the applied $\mathrm{C}$ for decades to centuries in soil [16] [17] [18] [19]. Biochar also contains elements of macronutrients (N, P, K, $\mathrm{Ca}, \mathrm{Mg}$ ), micronutrients $(\mathrm{Cu}, \mathrm{Zn}, \mathrm{Fe}, \mathrm{Mn})$, and ashes that accounting for $5 \%$ $60 \%$ of the weight [20] [21] [22]. Carbon content mostly increases with increasing pyrolysis temperature, while the nitrogen $(\mathrm{N})$ content decreases [16]. Biochar $\mathrm{pH}$ and nutrient contents vary with source materials and pyrolysis conditions: the $\mathrm{pH}$ of biochar ranges from 5.6 to $13.0, \mathrm{C}$ from $33.0 \%$ to $82.7 \%, \mathrm{~N}$ from $0.1 \%$ to $6.0 \%$, and the C:N ratio from 19 to 221 [16].

Due to these physical and chemical properties, biochar application has been advocated as a potential management strategy to improve soil quality, increase crop yield, reduce greenhouse gas emissions, and enhance soil C sequestration [2] [23]-[28]. Over the last decades, biochar has gained increasing attention and has been used in agriculture [1] [4] [5] [18] [23] [29]-[36]. This mini-review summarizes current results of the impacts of biochar application on different aspects from soil physical, chemical, and microbial properties, to nutrient conditions, plant growth and biomass, greenhouse gas emissions, and soil C sequestration. A framework of biochar impacts is summarized and possible mechanisms are discussed. Further research is proposed to verify the mechanisms involved in biochar-soil-microbial-plant interactions for soil enhancement and for crop biomass and yield improvements.

\section{Effects of Biochar Application on Soil Physical and Chemical Properties}

In the past decades, many studies have extensively investigated the impacts of biochar application on soil properties [13] [22] [37] [38]. In general, biochar application has improved soil physical and chemical properties, including soil $\mathrm{pH}$, nutrient status and cation-exchange capacity (CEC), and soil stoichiometry [1] [9] [39] [40] [41] [42] [43].

Some studies reported that biochar application improves soil physical properties by increasing porosity, decreasing bulk density, and enhancing aggregation and water retention [8] [44]. Biochar reduces soil acidity by $31.9 \%$ through liming effect (alkaline pine biochar can lime soils by 1.0 - 1.4 units) [45] [46] [47] [48]. In addition, biochar application has positive impacts on cation exchange capacity and electrical conductivity [49] [50]. It was reported that biochar can increase cation exchange capacity by $20 \%$ and soil electrical conductivity by 


\section{$124.6 \%[46][51]$.}

Soil water holding capacity is an important variable related to soil available water plants can use. Singh et al. [5] reported enhanced water retention in soils with biochar application due to the high porosity of biochar. Most studies found that biochar application increases soil water holding capacity and decreases the number of irrigations required [4] [5] [29] [52]. In addition, biochar application alters soil stoichiometry due to the change in organic $\mathrm{C}$ inputs of biochar. Studies found that the enhanced soil organic $\mathrm{C}$ inputs in some temperate ecosystems greatly immobilize microbial $\mathrm{N}$ into biomass [53] and stabilize soil microbial $\mathrm{N}$ [49] [54] [55]. The changes in soil dissolved organic $\mathrm{C}$ and $\mathrm{NO}_{3}^{-}$induced by biochar application are linked to the soil nitrous oxide $\left(\mathrm{N}_{2} \mathrm{O}\right)$ emission [56].

The changes of soil physical structure and chemical properties with biochar application are attributable to the properties of biochar (Figure 1), as the porous structure of biochar increases soil porosity and reduces bulk density [8] [38]. These changes would enable biochar to change soil $\mathrm{pH}$, enhance water holding capacity, and absorb and attach more nutrients in soil [5] [49] [56].

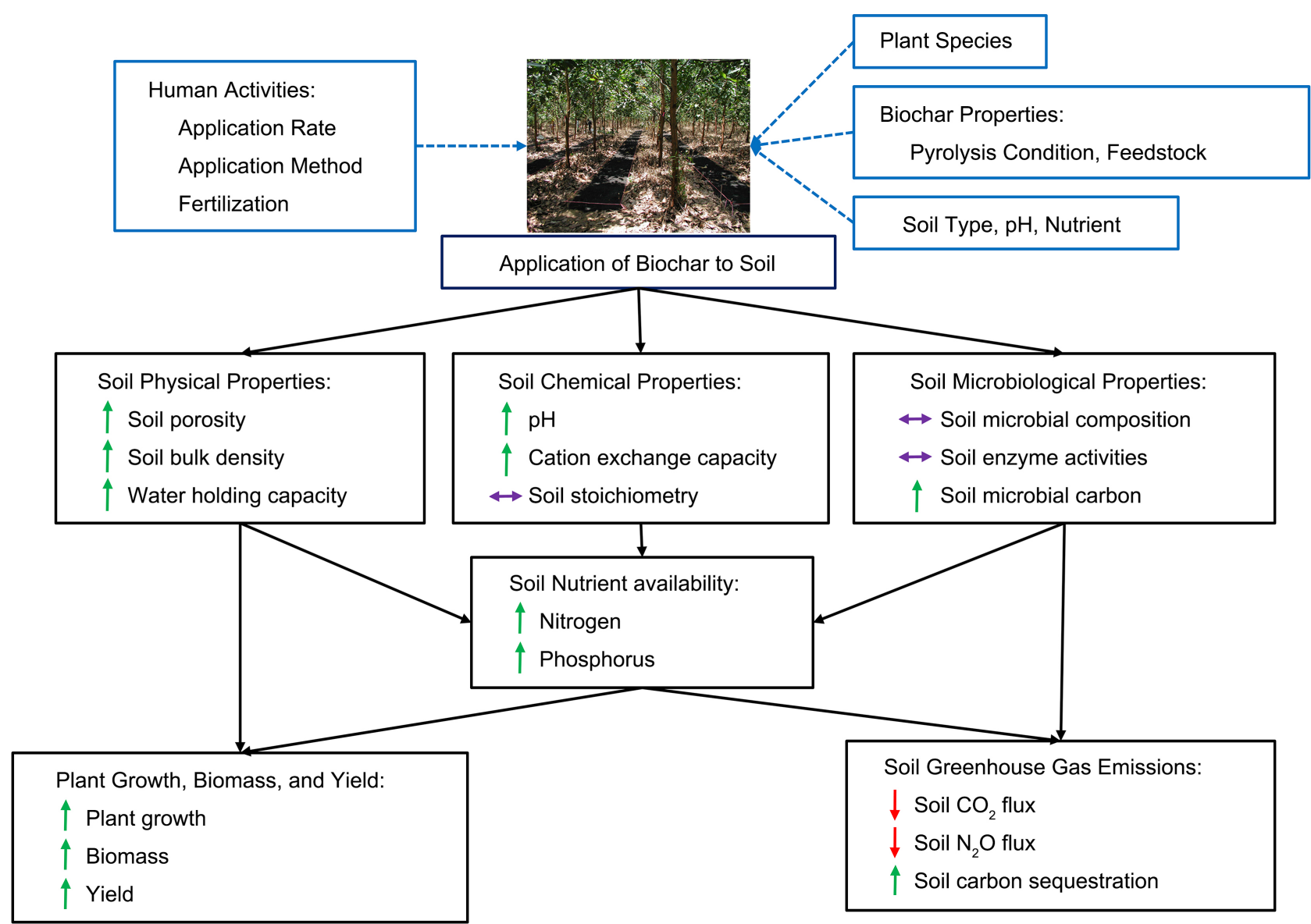

Figure 1. Framework of the impacts of biochar application to soil on soil properties, plant biomass and yield, and greenhouse gas emissions. The blue boxes are factors that may influence the responses to biochar application. Green up arrow indicates major positive effect, red down arrow indicates major negative effects, and purple double arrow indicates multiple impacts by biochar application. 


\section{Effects of Biochar Addition on Soil Microbial Composition and Activity}

Biochar application improves not only soil physical and chemical properties but also soil microbial properties [8]. The large surface area and reactivity of biochar attract ions and organic compounds, and increase potential sites for microbe-substrate interactions [57]. As a result, biochar application has a potential to change soil microbial community composition, influence microbial activity, and affect the soil enzyme activity that influencing various biogeochemical processes [38] [58]. Biochar application often shifts soil microbial populations into soil beneficial fungi and plant growth-promoting rhizobacteria [4] [59]. Fox et al. [60] found that biochar application increases abundances of genera of phosphorus (P) mobilizing bacteria. The abundance of living cells of root nodule bacteria is also increased by biochar application [61]. Mitchell et al. [62] found that biochar application significantly promotes the ratios of Gram-positive/Gram-negative bacteria and leads to high $\mathrm{CO}_{2}$ emissions. In addition, biochar application decreases the abundance of mycorrhizal fungi by reducing mycorrhizal symbiosis requirements for nutrients and water, and has direct negative effects on mycorrhiza formation [4] [63] [64]. Ishii and Kadoya [65] reported biochar produces higher rates of root colonization by arbuscular mycorrhizal (AM) fungi. Rillig et al. [66] also found positive effects on AM fungal root colonization, as biochar stimulates germination of spores of an AM fungus. Biochar application favors some zoospore-forming pathogens [67].

Biochar can activate soil microorganisms and increase soil microorganism activities [4] [68] [69]. For example, Kolb et al. [70] found that biochar application increases soil microbe respiration activity. Similarly, Steiner et al. [71] reported that, after biochar application, basal respiration is increased by $30.1 \%$. However, the opposite effect of biochar addition on microbial activity is observed [72]. Biochar reduces the activity of dehydrogenase and esterase by blocking or absorption of substrates [4] [73].

Soil microbial biomass $\mathrm{C}(\mathrm{MBC})$ is an important labile $\mathrm{C}$ fraction and plays a fundamental role in soil organic C dynamics [49] [54] [74] [75]. Studies have shown that biochar application to acid soils stimulates microbial activity and in turn increases soil MBC content and light fraction organic C [71] [76] [77]. Liang et al. [78] reported that biochar increases soil microbial biomass by $43 \%$ $125 \%$. Other studies also found that soil MBC content is higher in the biochar treated soils than in the control [16] [79] [80].

The changes in soil microbial community composition, biomass, and activities with biochar application could also be attributed to physical and chemical properties of biochar as well as biochar-induced changes in soil properties [57] [66] [81] [82]. For example, biochar can provide readily available nutrients for soil microbes and the addition of a small labile component can stimulate microbial activity [13] [83] [84] [85]. 


\section{Effects of Biochar Addition on Soil Nutrients}

Biochar addition alters nutrient cycles by directly adding nutrients $(\mathrm{N}, \mathrm{P}, \mathrm{K}, \mathrm{Ca}$, $\mathrm{Mg}$ ) in biochar to the soil [86] and by indirectly influencing the exchange of nutrients due to increased reactive surfaces [87] [88]. The effects of biochar application on $\mathrm{N}$ dynamics and $\mathrm{N}$-cycling enzymes remains ambiguous [89], as soil $\mathrm{N}$ mineralization has been found to decrease [90], increase [74], and remain unchanged [91] after biochar application [49]. Biochar addition mostly modifies $\mathrm{N}$ fluxes in soil and reduces gaseous $\mathrm{N}$ emissions [92]. Studies found that biochar increases nitrification activity in forest soils, but not in grassland soils, and enhances cation exchange capacity [4] [93]. Biochar changes soil nitrogenase dynamics and accelerates $\mathrm{N}$ dynamics [94]. Mia et al. [95] also showed that biochar application influences nodules formation and $\mathrm{N}$ fixation.

Biochar of different origins has different impacts on soil nutrients, as raw biomass materials vary in nutrient contents [14] [29] [50] [96]. For example, biochar made from Miscanthus can be used as a slow release silicon fertilizer [97] and animal bone biochar is a good P fertilizer [98] [99]. On the one hand, biochar can lower P bioavailability due to adsorption of orthophosphate and organic $\mathrm{P}$ compounds to its surface [51]. On the other hand, biochar decreases nutrient leaching [4] [100], as a result, there are more available P for plants in biochar-enriched soils [101] [102].

Several mechanisms have been proposed for the increase of soil nutrient availability including 1) the initial addition of soluble nutrients from biochar [29] and the mineralization of the labile fraction of biochar [13]; 2) reduction of nutrient leaching due to biochar's physicochemical properties [79]; and 3) reduced $\mathrm{N}$ losses by ammonia volatilization and $\mathrm{N}_{2} \mathrm{O}$ from denitrification [8] [55].

\section{Effects of Biochar Addition on Plant Growth, Biomass Production, Yield, and Resource Use Efficiencies}

While the effects of biochar vary with experimental conditions such as crop species, soil types and environments, biochar properties, and biochar application rates, methods, and frequencies [103], benefits of biochar application for plant biomass production and crop yields have been well documented in the literature [16] [39] [83] [104]. Biomass of crops is often enhanced by biochar application. For example, Novak et al. [105] reported an $81 \%$ increase in above- and below-ground biomass of winter wheat treated with biochar compared to the untreated control [5]. Above-ground biomass is enhanced by $25 \%$ with biochar application [16] [32]. The average biomass increase of agricultural crops with biochar application is $10 \%-30 \%$ [16] [32] [39] [103]. Some studies found that higher growth responses generally occurred in legume than non-legume crops [3] [103]. Biochar addition also increases the biomass of the roots of maize [106] and barley [107], and Satsuma mandarin trees [65]. Due to a higher P content of biochar-enriched soil, biochar addition may inhibit the development of root hairs [107]. 
Biochar has greater impacts on plants grown in nutrient-rich soils compared to in poor soils [108]. Positive growth responses with biochar application are more common, particularly in coarse-textured or acidic soils [83]. Strong positive plant responses to biochar are also reported in acidic infertile tropical soils, due to soluble P from biochar and P retention by biochar [109], sorption of salts [110] [111], and soil liming effects [112].

Crop yields are often improved by biochar application, particularly on highly weathered soils or sandy soils and moderately acidic soils [39] [103] [113] [114] [115]. Lehman et al. (2006) reported a higher increase of $20 \%$ - $120 \%$ in crop productivity with biochar addition. Maize grain yield can be significantly increased by $98 \%$ - 150\% after the application of biochar [18] [116]. Zhang et al. [117] reported $8.8 \%$ - 14\% increase in rice yields. Harvest index of double rice production is significantly increased [118]. However, decreases in crop productivity have also been reported for specific combinations of biochar and soil [45] [119]. Grain yields are decreased by $10 \%$ - 23.3\% with biochar application [120]. Spokas et al. [83] reviewed the biochar literature and found that $30 \%$ of the studies reported no significant differences, and 20\% reported negative yield or growth effects [83] [105].

The increases in crop production and yields are mostly attributed to that biochar application improves soil physical and chemical properties, nutrient supply or fertilizer use efficiencies [5] [83] [121]. Wheat yield and fertilizer use efficiency are increased with biochar application in dryland Australia [122]. High fertilizer use efficiencies are also reported in biochar amended low fertility soils [5] [123] [124]. The decreased crop yield may be attributed to toxic and harmful substances in biochar, which can reduce nutrient uptake and inhibit plant growth.

\section{Effects of Biochar Addition on Soil Greenhouse Gas Emissions and Carbon Sequestration}

Biochar application may mitigate climate change by reducing greenhouse gases (GHG) emissions and increasing soil C sequestration [1] [27] [125] [126], but the precise effects of biochar application on soil GHG emissions remain controversial and vary among different studies [127] [128]. Soil $\mathrm{CO}_{2}, \mathrm{CH}_{4}$, and $\mathrm{N}_{2} \mathrm{O}$ fluxes increase significantly in some studies [129] [130] [131], but substantially decrease or remain unchanged in others [132] [133] [134] [135]. For example, biochar application to paddy soils induces a $12 \%$ increase in $\mathrm{CO}_{2}$ emissions, but a $41.8 \%$ decrease in $\mathrm{N}_{2} \mathrm{O}$ emissions [136]. Another field experiment showed no significant effects of biochar application on soil $\mathrm{CO}_{2}$ and $\mathrm{N}_{2} \mathrm{O}$ emissions in a pasture ecosystem [137]. Thus, the impacts of biochar application are still uncertain due to these variable effects on soil GHG emissions.

Increases in soil $\mathrm{CO}_{2}$ fluxes with biochar application have been reported in several studies but with large uncertainties [27] [130] [136] [138]. Reduced soil $\mathrm{CO}_{2}$ fluxes or no effect of biochar amendment were found in some studies (e.g., 
[139] [140] [141] [142]. The change in soil $\mathrm{CO}_{2}$ emission rate could be related to several factors such as soil temperature, soil type and disturbance intensity, biochar pyrolysis temperature, and biochar application rates [143] [144]. This increase in soil $\mathrm{CO}_{2}$ emission after biochar application may result from a number of processes: 1) biotic use of biochar and biochar decomposition [145] [146], 2) release of biochar-C such as carbonates [37] [147] [148]; 3) priming of native soil organic $\mathrm{C}$ pools due to interactions between biochar and native soil organic matter [37] [146]. In addition, [62] found that biochar addition significantly promotes the ratios of Gram-positive/Gram-negative bacteria, and potentially leads to increased $\mathrm{CO}_{2}$ fluxes from soil organic $\mathrm{C}$ decomposition. The changes could also be a direct addition of relatively labile C of biochar [79] [145] [148].

Effects of biochar application on $\mathrm{CH}_{4}$ emissions from soils have been reported to vary remarkably in the literature, with results from reduced $\mathrm{CH}_{4}$ emissions to no changes, and to elevated emissions [149] [150] [151] [152] [153]. It appears that responses of $\mathrm{CH}_{4}$ emissions to biochar depend on the soil type, biochar properties, and the agricultural practices (e.g., fertilization and water management). Most studies reported biochar addition significantly reduces $\mathrm{CH}_{4}$ emissions [141] [153] [154] [155] [156]. For example, Rondon et al. [157] [158] found suppressions of $\mathrm{CH}_{4}$ emissions from soils treated with biochar in a grass stand, a soybean cropland, and a tropical soil. Qin et al. [118] reported that biochar amendment significantly decreased $\mathrm{CH}_{4}$ [118] [157] [158]. The reduction in $\mathrm{CH}_{4}$ emission is primarily ascribed to an increase in soil $\mathrm{pH}$, enhanced adsorption by soil particles, and the stimulated biodiversity and abundance of methanotrophic [118] [133] [159] [160] [161]. In contrast, other studies reported increased $\mathrm{CH}_{4}$ emissions or no significant effect of biochar addition. For example, Knoblauch et al. (2008) reported no significant change in $\mathrm{CH}_{4}$ production from a calcareous Fluvisol in both field and laboratory experiments [154]. Jia et al. [162] also reported no changes in $\mathrm{CH}_{4}$ in a vegetable production system. But Zhang et al. [153] found that total soil $\mathrm{CH}_{4}$ emissions are increased by $34 \%$ with $\mathrm{N}$ fertilization and $41 \%$ without $\mathrm{N}$ fertilization. The increased $\mathrm{CH}_{4}$ production with biochar addition is attributed to the input of labile organic substrates reduced soil redox potential [163] [164] [165], and an improved favorable environment for microbial activity [13] [166].

While studies have reported inconsistent findings on the effects of biochar application on soil $\mathrm{N}_{2} \mathrm{O}$ emission, most studies found that biochar contributes to the reduction in $\mathrm{N}_{2} \mathrm{O}$ emissions from soil [4] [131] [158]. For example, biochar application reduces soil $\mathrm{N}_{2} \mathrm{O}$ emission by $50 \%$ in soybean plots on acidic soils, by $61 \%-72 \%$ in Tenosol soil, and $17 \%-23 \%$ in Ferrosol soil [56]. Responses of $\mathrm{N}_{2} \mathrm{O}$ emission is related to soil moisture content as demonstrated in a laboratory study [131]. When comparing biochar effects, pot and field experiments need to be separated, as soil $\mathrm{N}_{2} \mathrm{O}$ emission reductions are $50 \%$ less under field versus laboratory conditions [167] [168]. Jia et al. [162] also reported significant decreases in soil $\mathrm{N}_{2} \mathrm{O}$ emission with biochar addition in a vegetable production system. 
Mechanisms such as increased soil aeration, $\mathrm{NO}_{3}^{-}$and $\mathrm{NH}_{4}^{+}-\mathrm{N}$ sorption, increased soil $\mathrm{pH}$, and enhanced $\mathrm{N}_{2} \mathrm{O}$ reductase activity have been identified [55] [162] [169]. A toxic effect induced by biochar organic compounds on nitrifier and denitrifier communities may cause a reduction in soil $\mathrm{N}_{2} \mathrm{O}$ emission [127] [170] [171] [172]. In contrast, increases in soil $\mathrm{N}_{2} \mathrm{O}$ emissions may be ascribed to biochar-induced increases in soil water content, which favors denitrification, the release of biochar embodied-N, and dissolved organic C content [138] [173].

Intense investigations have been conducted on the effects of biochar on $\mathrm{C}$ sequestration in agricultural and forest ecosystems [25] [62] [145] [174] [175] [176]. Biochar may increase, decrease or have no effect on soil organic C mineralization rates [27] [140] [143] [176]. Most studies reported positive effects for C sequestration, soil fertility, and contaminant immobilization [5] [29] [38] [177] [178], as biochar is highly recalcitrant in soil [23] [103] [179]. Biochar application increases not only soil organic matter and mineral contents but also the stability of aggregate $\mathrm{C}$ fractions, as biochar can form cationic bridges with soil minerals [57] [180] [181]. Carboxylic and phenolic functional groups in biochar bind minerals and soil organic matter [76] [182], and contribute to soil aggregation [57]. Maestrini et al. [183] showed that labile C fractions induce a short-term positive priming effect on native SOC, but over long-term, the priming effect may become weak due to sorption of dissolved organic $\mathrm{C}$ by biochar.

\section{Conclusions and Future Research}

Biochar application has great impacts on soil physical, chemical, and biological properties, plant growth, and crop yield. It directly affects soil bulk density, $\mathrm{pH}$, water holding capacity, and nutrients contents. Due to the vast differences in biochar, its application methods and rates, the responses of soils and plants to biochar application vary dramatically among different experimental studies [184]. While some studies reported negative effects of biochar on soil nutrient availability and plant growth, a majority of studies found that biochar application improves soil fertility, increases soil water holding capacity, enhances crop yields, reduces GHG emissions, and increases soil C storage (Figure 1).

The positive responses to biochar application have been attributed to several mechanisms [4] [127] including 1) improved nutrient availabilities and soil water retention to enhance plant biomass and crop yield [52] [87] [107] [185]; 2) stimulated soil microbial processes by absorbing/detoxifying inhibitory compounds [67] [186] [187] [188]; 3) reduced enzymatic activity and the precipitation of $\mathrm{CO}_{2}$ onto the biochar surface to reduce soil $\mathrm{CO}_{2}$ emission [134]; and 4) decreased $\mathrm{N}_{2} \mathrm{O}$ emissions due to improved soil aeration and soil $\mathrm{pH}$, and reduced activities of nitrifier and denitrifier [170] [171] [172].

Despite great interests of using biochar to manage soils are increasing and many studies have been conducted with biochar application, large uncertainties of biochar effects still exist [8]. Future research is needed with focuses on these several aspects: 1) to create a linkage and association among biochar properties, 
soil properties and processes, plant species, and sources of variation to biochar application; 2) understand the mechanisms of biochar responses with regard to the newly found electron transfer and free radical activation functions of biochar [9] [189] [190]; 3) detect the interactions of biochar with climatic factors such as global warming, precipitation changes and agricultural practices like no-tillage and $\mathrm{N}$ application; and 4) conduct systematic studies of soil and plant responses to biochar in field experiments across a larger spatial scale and over a long term.

Understanding these complex plant-soil-microbial interactions is important for developing soil management and conservation practices to improve soil properties and agricultural productivity. To accurately quantify the effects of biochar application on soil properties, crop biomass production and yield, GHG emissions, and soil C sequestration, a coordinated large-scale biochar field study may be needed. It is critical that the new experiments are designed with the same protocols and include different crop systems, soil types, biochar types and application rates, and fertilization status so that the sources of variation could be distinguished, and the mechanisms could be uncovered [191]. The experiments should be run at least 3 5 years with biochar application in the field, using the same protocols for field measurements. As such studies will help us understand the role of environmental factors in controlling biochar-induced changes in soil chemical and biological properties. More model simulations of biochar effects on soil and plant considering different application approaches and rates are also needed.

\section{Acknowledgements}

D.H. is supported by the US National Science Foundation (NSF) TIP (1623085), MRI (1919897), and EiR $(1900885,2000058)$ projects. Hashim Alsadah helped with the preparation of the manuscript.

\section{Author's Contributions}

Conceptualization, D.H.; writing—original draft preparation, D.H.; writing—review and editing, D.H.

\section{Funding}

This research was funded by the United States National Science Foundation (NSF) project.

\section{Conflicts of Interest}

The author declares no conflict of interest. The funders had no role in the design of the study; in the collection, analyses, or interpretation of data; in the writing of the manuscript, or in the decision to publish the results.

\section{References}

[1] Lehmann, J. (2007) Bio-Energy in the Black. Frontiers in Ecology and the Environment, 5, 381-387. https://doi.org/10.1890/1540-9295(2007)5[381:BITB]2.0.CO;2 
[2] Laird, D.A., Brown, R.C., Amonette, J.E. and Lehmann, J. (2009) Review of the Pyrolysis Platform for Coproducing Bio-Oil and Biochar. Biofuels Bioproducts \& Biorefining, 3, 547-562. https://doi.org/10.1002/bbb.169

[3] Thomas, S.C. and Gale, N. (2015) Biochar and Forest Restoration: A Review and Meta-Analysis of Tree Growth Responses. New Forests, 46, 931-946. https://doi.org/10.1007/s11056-015-9491-7

[4] Gluszek, S., Sas-Paszt, L., Sumorok, B. and Kozera, R. (2017) Biochar-Rhizosphere Interactions-A Review. Polish Journal of Microbiology, 66, 151-161. https://doi.org/10.5604/01.3001.0010.6288

[5] Arif, M., Ilyas, M., Riaz, M., Ali, K., Shan, K., Haq, I.U. and Fahad, S. (2017) Biochar Improves Phosphorus Use Efficiency of Organic-Inorganic Fertilizers, Maize-Wheat Productivity and Soil Quality in a Low Fertility Alkaline Soil. Field Crops Research, 214, 25-37. https://doi.org/10.1016/j.fcr.2017.08.018

[6] Chan, K.Y., Van Zwieten, L., Meszaros, I., Downie, A. and Joseph, S. (2008) Using Poultry Litter Biochars as Soil Amendments. Australian Journal of Soil Research, 46, 437-444. https://doi.org/10.1071/SR08036

[7] Bridgwater, A.V. and Peacocke, G.V.C. (2000) Fast Pyrolysis Processes for Biomass. Renewable \& Sustainable Energy Reviews, 4, 1-73. https://doi.org/10.1016/S1364-0321(99)00007-6

[8] Ding, Z.H., Wan, Y.S., Hu, X., Wang, S.S., Zimmerman, A.R. and Gao, B. (2016) Sorption of Lead and Methylene Blue onto Hickory Biochars from Different Pyrolysis Temperatures: Importance of Physicochemical Properties. Journal of Industrial and Engineering Chemistry, 37, 261-267. https://doi.org/10.1016/j.jiec.2016.03.035

[9] Xiang, Y.Z., Deng, Q., Duan, H.L. and Guo, Y. (2017) Effects of Biochar Application on Root Traits: A Meta-Analysis. Global Change Biology Bioenergy, 9, 1563-1572. https://doi.org/10.1111/gcbb.12449

[10] Schmidt, M.W.I., Skjemstad, J.O. and Jager, C. (2002) Carbon Isotope Geochemistry and Nanomorphology of Soil Black Carbon: Black Chernozemic Soils in Central Europe Originate from Ancient Biomass Burning. Global Biogeochemical Cycles, 16, 70-1-70-8. https://doi.org/10.1029/2002GB001939

[11] Joseph, S.D., Camps-Arbestain, M., Lin, Y., Munroe, P., Chia, C.H., Hook, J., van Zwieten, L., Kimber, S., Cowie, A., Singh, B.P., et al. (2010) An Investigation into the Reactions of Biochar in Soil. Australian Journal of Soil Research, 48, 501-515. https://doi.org/10.1071/SR10009

[12] Bruun, E.W., Hauggaard-Nielsen, H., Ibrahim, N., Egsgaard, H., Ambus, P., Jensen, P.A. and Dam-Johansen, K. (2011) Influence of Fast Pyrolysis Temperature on Biochar Labile Fraction and Short-Term Carbon Loss in a Loamy Soil. Biomass \& Bioenergy, 35, 1182-1189. https://doi.org/10.1016/j.biombioe.2010.12.008

[13] Lehmann, J., Rillig, M.C., Thies, J., Masiello, C.A., Hockaday, W.C. and Crowley, D. (2011) Biochar Effects on Soil Biota-A Review. Soil Biology \& Biochemistry, 43, 1812-1836. https://doi.org/10.1016/j.soilbio.2011.04.022

[14] Atkinson, C.J., Fitzgerald, J.D. and Hipps, N.A. (2010) Potential Mechanisms for Achieving Agricultural Benefits from Biochar Application to Temperate Soils: A Review. Plant and Soil, 337, 1-18. https://doi.org/10.1007/s11104-010-0464-5

[15] Kammann, C.I., Schmidt, H.P., Messerschmidt, N., Linsel, S., Steffens, D., Muller, C., Koyro, H.W., Conte, P. and Stephen, J. (2015) Plant Growth Improvement Mediated by Nitrate Capture in Co-Composted Biochar. Scientific Reports, 5, Article No. 12378. https://doi.org/10.1038/srep12378 
[16] Biederman, L.A. and Harpole, W.S. (2013) Biochar and Its Effects on Plant Productivity and Nutrient Cycling: A Meta-Analysis. Global Change Biology Bioenergy, 5, 202-214. https://doi.org/10.1111/gcbb.12037

[17] Novak, J.M., Busscher, W.J., Watts, D.W., Laird, D.A., Ahmedna, M.A. and Niandou, M.A.S. (2010) Short-Term $\mathrm{CO}_{2}$ Mineralization after Additions of Biochar and Switchgrass to a Typic Kandiudult. Geoderma, 154, 281-288.

https://doi.org/10.1016/j.geoderma.2009.10.014

[18] Lehmann, J., Gaunt, J. and Rondon, M. (2006) Bio-Char Sequestration in Terrestrial Ecosystems-A Review. Mitigation and Adaptation Strategies for Global Change, 11, 403-427. https://doi.org/10.1007/s11027-005-9006-5

[19] Wardle, D.A., Nilsson, M.C. and Zackrisson, O. (2008) Fire-Derived Charcoal Causes Loss of Forest Humus. Science, 320, 629-629. https://doi.org/10.1126/science. 1154960

[20] Enders, A., Hanley, K., Whitman, T., Joseph, S. and Lehmann, J. (2012) Characterization of Biochars to Evaluate Recalcitrance and Agronomic Performance. Bioresource Technology, 114, 644-653. https://doi.org/10.1016/j.biortech.2012.03.022

[21] Zhang, C.J., Clark, G.J., Patti, A.F., Bolan, N., Cheng, M.M., Sale, P.W.G. and Tang, C.X. (2015) Contrasting Effects of Organic Amendments on Phytoextraction of Heavy Metals in a Contaminated Sediment. Plant and Soil, 397, 331-345. https://doi.org/10.1007/s11104-015-2615-1

[22] Chen, B.L., Zhou, D.D. and Zhu, L.Z. (2008) Transitional Adsorption and Partition of Nonpolar and Polar Aromatic Contaminants by Biochars of Pine Needles with Different Pyrolytic Temperatures. Environmental Science \& Technology, 42, 5137-5143. https://doi.org/10.1021/es8002684

[23] Woolf, D., Amonette, J.E., Street-Perrott, F.A., Lehmann, J. and Joseph, S. (2010) Sustainable Biochar to Mitigate Global Climate Change. Nature Communications, 1, 56. https://doi.org/10.1038/ncomms1053

[24] Case, S.D.C., McNamara, N.P., Reay, D.S. and Whitaker, J. (2012) The Effect of Biochar Addition on $\mathrm{N}_{2} \mathrm{O}$ and $\mathrm{CO}_{2}$ Emissions from a Sandy Loam Soil-The Role of Soil Aeration. Soil Biology \& Biochemistry, 51, 125-134. https://doi.org/10.1016/j.soilbio.2012.03.017

[25] Liu, X.Y., Zheng, J.F., Zhang, D.X., Cheng, K., Zhou, H.M., Zhang, A., Li, L.Q., Joseph, S., Smith, P., Crowley, D., et al. (2016) Biochar Has No Effect on Soil Respiration across Chinese Agricultural Soils. Science of the Total Environment, 554, 259-265. https://doi.org/10.1016/j.scitotenv.2016.02.179

[26] Ding, Y., Liu, Y.G., Liu, S.B., Li, Z.W., Tan, X.F., Huang, X.X., Zeng, G.M., Zhou, L. and Zheng, B.H. (2016) Biochar to Improve Soil Fertility. A Review. Agronomy for Sustainable Development, 36, Article No. 36. https://doi.org/10.1007/s13593-016-0372-Z

[27] Liu, S.W., Zhang, Y.J., Zong, Y.J., Hu, Z.Q., Wu, S., Zhou, J., Jin, Y.G. and Zou, J.W. (2016) Response of Soil Carbon Dioxide Fluxes, Soil Organic Carbon and Microbial Biomass Carbon to Biochar Amendment: A Meta-Analysis. Global Change Biology Bioenergy, 8, 392-406. https://doi.org/10.1111/gcbb.12265

[28] Ding, F., Van Zwieten, L., Zhang, W.D., Weng, Z., Shi, S.W., Wang, J.K. and Meng, J. (2018) A Meta-Analysis and Critical Evaluation of Influencing Factors on Soil Carbon Priming Following Biochar Amendment. Journal of Soils and Sediments, 18, 1507-1517. https://doi.org/10.1007/s11368-017-1899-6

[29] Sohi, S.P., Krull, E., Lopez-Capel, E. and Bol, R. (2010) A Review of Biochar and Its 
Use and Function in Soil. Advances in Agronomy, 105, 47-82. https://doi.org/10.1016/S0065-2113(10)05002-9

[30] Liu, N., Zhou, C.J., Fu, S.F., Ashraf, M.I., Zhao, E.F., Shi, H. and Han, X.R. (2013) Study on Characteristics of Ammonium Nitrogen Adsorption by Biochar Prepared in Different Temperature. Applied Energy Technology, Pts 1 and 2, 724-725, 452-456. https://doi.org/10.4028/www.scientific.net/AMR.724-725.452

[31] Wang, D.Y., Griffin, D.E., Parikh, S.J. and Scow, K.M. (2016) Impact of Biochar Amendment on Soil Water Soluble Carbon in the Context of Extreme Hydrological Events. Chemosphere, 160, 287-292.

https://doi.org/10.1016/j.chemosphere.2016.06.100

[32] Crane-Droesch, A., Abiven, S., Jeffery, S. and Torn, M.S. (2013) Heterogeneous Global Crop Yield Response to Biochar: A Meta-Regression Analysis. Environmental Research Letters, 8, Article ID: 044049. https://doi.org/10.1088/1748-9326/8/4/044049

[33] Mukherjee, A., Lal, R. and Zimmerman, A.R. (2014) Impacts of 1.5-Year Field Aging on Biochar, Humic Acid, and Water Treatment Residual Amended Soil. Soil Science, 179, 333-339. https://doi.org/10.1097/SS.0000000000000076

[34] Xu, C.Y., Hosseini-Bai, S., Hao, Y.B., Rachaputi, R.C.N., Wang, H.L., Xu, Z.H. and Wallace, H. (2015) Effect of Biochar Amendment on Yield and Photosynthesis of Peanut on Two Types of Soils. Environmental Science and Pollution Research, 22, 6112-6125. https://doi.org/10.1007/s11356-014-3820-9

[35] He, H.Z., Pan, J.J., Yu, P.F., Chen, G.K. and Lu, H.S. (2017) Effects of Hybrid Giant Napier Biochar on Cadmium Migration in a Cabbage-Soil System Contaminated with Cadmium and Butachlor. Polish Journal of Environmental Studies, 26, 619-625. https://doi.org/10.15244/pjoes/65362

[36] Darby, I., Xu, C.Y., Wallace, H.M., Joseph, S., Pace, B. and Bai, S.H. (2016) Short-Term Dynamics of Carbon and Nitrogen Using Compost, Compost-Biochar Mixture and Organo-Mineral Biochar. Environmental Science and Pollution Research, 23, 11267-11278. https://doi.org/10.1007/s11356-016-6336-7

[37] Ameloot, N., Neve, S., Jegajeevagan, K., Yildiz, G., Buchan, D., Funkuin, Y.N., Prins, W., Bouckaert, L. and Sleutel, S. (2013) Short-Term $\mathrm{CO}_{2}$ and $\mathrm{N}_{2} \mathrm{O}$ Emissions and Microbial Properties of Biochar Amended Sandy Loam Soils. Soil Biology \& Biochemistry, 57, 401-410. https://doi.org/10.1016/j.soilbio.2012.10.025

[38] Zhu, L.X., Xiao, Q., Cheng, H.Y., Shi, B.J., Shen, Y.F. and Li, S.Q. (2017) Seasonal Dynamics of Soil Microbial Activity after Biochar Addition in a Dryland Maize Field in North-Western China. Ecological Engineering, 104, 141-149. https://doi.org/10.1016/j.ecoleng.2017.04.026

[39] Jeffery, S., Verheijen, F.G.A., van der Velde, M. and Bastos, A.C. (2011) A Quantitative Review of the Effects of Biochar Application to Soils on Crop Productivity Using Meta-Analysis. Agriculture Ecosystems \& Environment, 144, 175-187. https://doi.org/10.1016/j.agee.2011.08.015

[40] Noguera, D., Barot, S., Laossi, K.R., Cardoso, J., Lavelle, P. and de Carvalho, M.H.C. (2012) Biochar But Not Earthworms Enhances Rice Growth through Increased Protein Turnover. Soil Biology \& Biochemistry, 52, 13-20. https://doi.org/10.1016/j.soilbio.2012.04.004

[41] Wang, X.B., Song, D.L., Liang, G.Q., Zhang, Q., Ai, C. and Zhou, W. (2015) Maize Biochar Addition Rate Influences Soil Enzyme Activity and Microbial Community Composition in a Fluvo-Aquic Soil. Applied Soil Ecology, 96, 265-272. 
https://doi.org/10.1016/j.apsoil.2015.08.018

[42] Quilliam, R.S., DeLuca, T.H. and Jones, D.L. (2013) Biochar Application Reduces Nodulation But Increases Nitrogenase Activity in Clover. Plant and Soil, 366, 83-92. https://doi.org/10.1007/s11104-012-1411-4

[43] Lehmann, J. and Joseph, S. (2015) Biochar for Environmental Management: Science, Technology and Implementation. Routledge, London. https://doi.org/10.4324/9780203762264

[44] Baiamonte, G., De Pasquale, C., Marsala, V., Cimo, G., Alonzo, G., Crescimanno, G. and Conte, P. (2015) Structure Alteration of a Sandy-Clay Soil by Biochar Amendments. Journal of Soils and Sediments, 15, 816-824. https://doi.org/10.1007/s11368-014-0960-y

[45] Van Zwieten, L., Kimber, S., Morris, S., Chan, K.Y., Downie, A., Rust, J., Joseph, S. and Cowie, A. (2010) Effects of Biochar from Slow Pyrolysis of Papermill Waste on Agronomic Performance and Soil Fertility. Plant and Soil, 327, 235-246. https://doi.org/10.1007/s11104-009-0050-x

[46] Oguntunde, P.G., Fosu, M., Ajayi, A.E. and van de Giesen, N. (2004) Effects of Charcoal Production on Maize Yield, Chemical Properties and Texture of Soil. Biology and Fertility of Soils, 39, 295-299. https://doi.org/10.1007/s00374-003-0707-1

[47] Chan, K.Y., Van Zwieten, L., Meszaros, I., Downie, A. and Joseph, S. (2007) Agronomic Values of Greenwaste Biochar as a Soil Amendment. Australian Journal of Soil Research, 45, 629-634. https://doi.org/10.1071/SR07109

[48] Rogovska, N., Laird, D.A., Rathke, S.J. and Karlen, D.L. (2014) Biochar Impact on Midwestern Mollisols and Maize Nutrient Availability. Geoderma, 230, 340-347. https://doi.org/10.1016/j.geoderma.2014.04.009

[49] Foster, E.J., Hansen, N., Wallenstein, M. and Cotrufo, M.F. (2016) Biochar and Manure Amendments Impact Soil Nutrients and Microbial Enzymatic Activities in a Semi-Arid Irrigated Maize Cropping System. Agriculture Ecosystems \& Environment, 233, 404-414. https://doi.org/10.1016/j.agee.2016.09.029

[50] Deluca, T., Fajvan, M.A. and Miller, G. (2009) Diameter-Limit Harvesting: Effects of Residual Trees on Regeneration Dynamics in Appalachian Hardwoods. Northern Journal of Applied Forestry, 26, 52-60. https://doi.org/10.1093/njaf/26.2.52

[51] Laird, D.A., Fleming, P., Davis, D.D., Horton, R., Wang, B.Q. and Karlen, D.L. (2010) Impact of Biochar Amendments on the Quality of a Typical Midwestern Agricultural Soil. Geoderma, 158, 443-449. https://doi.org/10.1016/j.geoderma.2010.05.013

[52] Ojeda, G., Mattana, S., Avila, A., Alcaniz, J.M., Volkmann, M. and Bachmann, J. (2015) Are Soil-Water Functions Affected by Biochar Application? Geoderma, 249, 1-11. https://doi.org/10.1016/j.geoderma.2015.02.014

[53] Güereña, D., Lehmann, J., Hanley, K., Enders, A., Hyland, C. and Riha, S. (2013) Nitrogen Dynamics Following Field Application of Biochar in a Temperate North American Maize-Based Production System. Plant and Soil, 365, 239-254. https://doi.org/10.1007/s11104-012-1383-4

[54] Brantley, K.E., Savin, M.C., Brye, K.R. and Longer, D.E. (2015) Pine Woodchip Biochar Impact on Soil Nutrient Concentrations and Corn Yield in a Silt Loam in the Mid-Southern U.S. Agriculture-Basel, 5, 30-47.

https://doi.org/10.3390/agriculture5010030

[55] Cayuela, M.L., Sanchez-Monedero, M.A., Roig, A., Hanley, K., Enders, A. and Lehmann, J. (2013) Biochar and Denitrification in Soils: When, How Much and Why 
Does Biochar Reduce $\mathrm{N}_{2} \mathrm{O}$ Emissions? Scientific Reports, 3, Article No. 1732. https://doi.org/10.1038/srep01732

[56] Lan, Z.M., Chen, C.R., Rashti, M.R., Yang, H. and Zhang, D.K. (2017) Stoichiometric Ratio of Dissolved Organic Carbon to Nitrate Regulates Nitrous Oxide Emission from the Biochar-Amended Soils. Science of the Total Environment, 576, 559-571. https://doi.org/10.1016/j.scitotenv.2016.10.119

[57] Gul, S., Whalen, J.K., Thomas, B.W., Sachdeva, V. and Deng, H.Y. (2015) Physico-Chemical Properties and Microbial Responses in Biochar-Amended Soils: Mechanisms and Future Directions. Agriculture Ecosystems \& Environment, 206, 46-59. https://doi.org/10.1016/j.agee.2015.03.015

[58] Paz-Ferreiro, J., Gasco, G., Gutierrez, B. and Mendez, A. (2012) Soil Biochemical Activities and the Geometric Mean of Enzyme Activities after Application of Sewage Sludge and Sewage Sludge Biochar to Soil. Biology and Fertility of Soils, 48, 511-517. https://doi.org/10.1007/s00374-011-0644-3

[59] Graber, E.R., Harel, Y.M., Kolton, M., Cytryn, E., Silber, A., David, D.R., Tsechansky, L., Borenshtein, M. and Elad, Y. (2010) Biochar Impact on Development and Productivity of Pepper and Tomato Grown in Fertigated Soilless Media. Plant and Soil, 337, 481-496. https://doi.org/10.1007/s11104-010-0544-6

[60] Fox, A., Gahan, J., Ikoyi, I., Kwapinski, W., O’Sullivan, O., Cotter, P.D. and Schmalenberger, A. (2016) Miscanthus Biochar Promotes Growth of Spring Barley and Shifts Bacterial Community Structures Including Phosphorus and Sulfur Mobilizing Bacteria. Pedobiologia, 59, 195-202. https://doi.org/10.1016/j.pedobi.2016.07.003

[61] Wang, J.Y., Dokohely, M.E., Xiong, Z.Q. and Kuzyakov, Y. (2016) Contrasting Effects of Aged and Fresh Biochars on Glucose-Induced Priming and Microbial Activities in Paddy Soil. Journal of Soils and Sediments, 16, 191-203.

https://doi.org/10.1007/s11368-015-1189-0

[62] Mitchell, P.J., Simpson, A.J., Soong, R. and Simpson, M.J. (2015) Shifts in Microbial Community and Water-Extractable Organic Matter Composition with Biochar Amendment in a Temperate Forest Soil. Soil Biology \& Biochemistry, 81, 244-254. https://doi.org/10.1016/j.soilbio.2014.11.017

[63] Warnock, D.D., Mummey, D.L., McBride, B., Major, J., Lehmann, J. and Rillig, M.C. (2010) Influences of Non-Herbaceous Biochar on Arbuscular Mycorrhizal Fungal Abundances in Roots and Soils: Results from Growth-Chamber and Field Experiments. Applied Soil Ecology, 46, 450-456.

https://doi.org/10.1016/j.apsoil.2010.09.002

[64] Gryndler, M., Larsen, J., Hrselova, H., Rezacova, V., Gryndlerova, H. and Kubat, J. (2006) Organic and Mineral Fertilization, Respectively, Increase and Decrease the Development of External Mycelium of Arbuscular Mycorrhizal Fungi in a Long-Term Field Experiment. Mycorrhiza, 16, 159-166.

https://doi.org/10.1007/s00572-005-0027-4

[65] Ishii, T. and Kadoya, K. (1994) Effects of Charcoal as a Soil Conditioner on Citrus Growth and Vesicular-Arbuscular Mycorrhizal Development. Journal of the Japanese Society for Horticultural Science, 63, 529-535. https://doi.org/10.2503/jjshs.63.529

[66] Rillig, M.C., Wagner, M., Salem, M., Antunes, P.M., George, C., Ramke, H.G., Titirici, M.M. and Antonietti, M. (2010) Material Derived from Hydrothermal Carbonization: Effects on Plant Growth and Arbuscular Mycorrhiza. Applied Soil Ecology, 45, 238-242. https://doi.org/10.1016/j.apsoil.2010.04.011 
[67] Thies, J.E. and Rillig, M.C. (2009) Characteristics of Biochar: Biochar Properties. In: Lehmann, J. and Joseph, S., Eds., Biochar for Environmental Management Science and Technology, Earthscan, London, 85-105.

[68] Kuzyakov, Y., Subbotina, I., Chen, H.Q., Bogomolova, I. and Xu, X.L. (2009) Black Carbon Decomposition and Incorporation into Soil Microbial Biomass Estimated by C-14 Labeling. Soil Biology \& Biochemistry, 41, 210-219.

https://doi.org/10.1016/j.soilbio.2008.10.016

[69] Knicker, H., Muffler, P. and Hilscher, A. (2007) How Useful Is Chemical Oxidation with Dichromate for the Determination of "Black Carbon" in Fire-Affected Soils? Geoderma, 142, 178-196. https://doi.org/10.1016/j.geoderma.2007.08.010

[70] Kolb, S.E., Fermanich, K.J. and Dornbush, M.E. (2009) Effect of Charcoal Quantity on Microbial Biomass and Activity in Temperate Soils. Soil Science Society of America Journal, 73, 1173-1181. https://doi.org/10.2136/sssaj2008.0232

[71] Steiner, C., Glaser, B., Teixeira, W.G., Lehmann, J., Blum, W.E.H. and Zech, W. (2008) Nitrogen Retention and Plant Uptake on a Highly Weathered Central Amazonian Ferralsol Amended with Compost and Charcoal. Journal of Plant Nutrition and Soil Science, 171, 893-899. https://doi.org/10.1002/jpln.200625199

[72] Chintala, R., Schumacher, T.E., Kumar, S., Malo, D.D., Rice, J.A., Bleakley, B., Chilom, G., Clay, D.E., Julson, J.L., Papiernik, S.K., et al. (2014) Molecular Characterization of Biochars and Their Influence on Microbiological Properties of Soil. Journal of Hazardous Materials, 279, 244-256.

https://doi.org/10.1016/j.jhazmat.2014.06.074

[73] Bailey, V.L., Fansler, S.J., Smith, J.L. and Bolton, H. (2011) Reconciling Apparent Variability in Effects of Biochar Amendment on Soil Enzyme Activities by Assay Optimization. Soil Biology \& Biochemistry, 43, 296-301.

https://doi.org/10.1016/j.soilbio.2010.10.014

[74] Domene, X., Mattana, S., Hanley, K., Enders, A. and Lehmann, J. (2014) Medium-Term Effects of Corn Biochar Addition on Soil Biota Activities and Functions in a Temperate Soil Cropped to Corn. Soil Biology \& Biochemistry, 72, 152-162. https://doi.org/10.1016/j.soilbio.2014.01.035

[75] Grandy, A.S. and Neff, J.C. (2008) Molecular C Dynamics Downstream: The Biochemical Decomposition Sequence and Its Impact on Soil Organic Matter Structure and Function. Science of the Total Environment, 404, 297-307.

https://doi.org/10.1016/j.scitotenv.2007.11.013

[76] Lin, Y., Munroe, P., Joseph, S., Henderson, R. and Ziolkowski, A. (2012) Water Extractable Organic Carbon in Untreated and Chemical Treated Biochars. Chemosphere, 87, 151-157. https://doi.org/10.1016/j.chemosphere.2011.12.007

[77] Demisie, W., Liu, Z.Y. and Zhang, M.K. (2014) Effect of Biochar on Carbon Fractions and Enzyme Activity of Red Soil. Catena, 121, 214-221.

https://doi.org/10.1016/j.catena.2014.05.020

[78] Liang, B.Q., Lehmann, J., Sohi, S.P., Thies, J.E., O’Neill, B., Trujillo, L., Gaunt, J., Solomon, D., Grossman, J., Neves, E.G., et al. (2010) Black Carbon Affects the Cycling of Non-Black Carbon in Soil. Organic Geochemistry, 41, 206-213. https://doi.org/10.1016/j.orggeochem.2009.09.007

[79] Liang, B., Lehmann, J., Solomon, D., Sohi, S., Thies, J.E., Skjemstad, J.O., Luizao, F.J., Engelhard, M.H., Neves, E.G. and Wirick, S. (2008) Stability of Biomass-Derived Black Carbon in Soils. Geochimica et Cosmochimica Acta, 72, 6069-6078. https://doi.org/10.1016/j.gca.2008.09.028 
[80] Liao, N., Li, Q., Zhang, W., Zhou, G.W., Ma, L.J., Min, W., Ye, J. and Hou, Z.N. (2016) Effects of Biochar on Soil Microbial Community Composition and Activity in Drip-Irrigated Desert Soil. European Journal of Soil Biology, 72, 27-34. https://doi.org/10.1016/j.ejsobi.2015.12.008

[81] Jindo, K., Sanchez-Monedero, M.A., Hernandez, T., Garcia, C., Furukawa, T., Matsumoto, K., Sonoki, T. and Bastida, F. (2012) Biochar Influences the Microbial Community Structure during Manure Composting with Agricultural Wastes. Science of the Total Environment, 416, 476-481. https://doi.org/10.1016/j.scitotenv.2011.12.009

[82] Tian, J., Wang, J.Y., Dippold, M., Gao, Y., Blagodatskaya, E. and Kuzyakov, Y. (2016) Biochar Affects Soil Organic Matter Cycling and Microbial Functions but Does Not Alter Microbial Community Structure in a Paddy Soil. Science of the Total Environment, 556, 89-97. https://doi.org/10.1016/j.scitotenv.2016.03.010

[83] Spokas, K.A., Cantrell, K.B., Novak, J.M., Archer, D.W., Ippolito, J.A., Collins, H.P., Boateng, A.A., Lima, I.M., Lamb, M.C., McAloon, A.J., et al. (2012) Biochar: A Synthesis of Its Agronomic Impact beyond Carbon Sequestration. Journal of Environmental Quality, 41, 973-989. https://doi.org/10.2134/jeq2011.0069

[84] Warnock, D.D., Lehmann, J., Kuyper, T.W. and Rillig, M.C. (2007) Mycorrhizal Responses to Biochar in Soil-Concepts and Mechanisms. Plant and Soil, 300, 9-20. https://doi.org/10.1007/s11104-007-9391-5

[85] Anderson, C.R., Condron, L.M., Clough, T.J., Fiers, M., Stewart, A., Hill, R.A. and Sherlock, R.R. (2011) Biochar Induced Soil Microbial Community Change: Implications for Biogeochemical Cycling of Carbon, Nitrogen and Phosphorus. Pedobiologia, 54, 309-320. https://doi.org/10.1016/j.pedobi.2011.07.005

[86] Gaskin, J.W., Steiner, C., Harris, K., Das, K.C. and Bibens, B. (2008) Effect of Low-Temperature Pyrolysis Conditions on Biochar for Agricultural Use. Transactions of the Asabe, 51, 2061-2069. https://doi.org/10.13031/2013.25409

[87] Gundale, M.J. and DeLuca, T.H. (2007) Charcoal Effects on Soil Solution Chemistry and Growth of Koeleria Macrantha in the Ponderosa Pine/Douglas-Fir Ecosystem. Biology and Fertility of Soils, 43, 303-311. https://doi.org/10.1007/s00374-006-0106-5

[88] Silber, A., Levkovitch, I. and Graber, E.R. (2010) pH-Dependent Mineral Release and Surface Properties of Cornstraw Biochar: Agronomic Implications. Environmental Science \& Technology, 44, 9318-9323. https://doi.org/10.1021/es101283d

[89] Ameloot, N., Sleutel, S., Das, K.C., Kanagaratnam, J. and de Neve, S. (2015) Biochar Amendment to Soils with Contrasting Organic Matter Level: Effects on N Mineralization and Biological Soil Properties. Global Change Biology Bioenergy, 7, 135-144. https://doi.org/10.1111/gcbb.12119

[90] Lentz, R.D., Ippolito, J.A. and Spokas, K.A. (2014) Biochar and Manure Effects on Net Nitrogen Mineralization and Greenhouse Gas Emissions from Calcareous Soil under Corn. Soil Science Society of America Journal, 78, 1641-1655.

https://doi.org/10.2136/sssaj2014.05.0198

[91] Gaskin, J.W., Speir, R.A., Harris, K., Das, K.C., Lee, R.D., Morris, L.A. and Fisher, D.S. (2010) Effect of Peanut Hull and Pine Chip Biochar on Soil Nutrients, Corn Nutrient Status, and Yield. Agronomy Journal, 102, 623-633. https://doi.org/10.2134/agronj2009.0083

[92] Rondon, M.A., Lehmann, J., Ramirez, J. and Hurtado, M. (2007) Biological Nitrogen Fixation by Common Beans (Phaseolus vulgaris L.) Increases with Bio-Char 
Additions. Biology and Fertility of Soils, 43, 699-708. https://doi.org/10.1007/s00374-006-0152-Z

[93] Glaser, B., Wiedner, K., Seelig, S., Schmidt, H.P. and Gerber, H. (2015) Biochar Organic Fertilizers from Natural Resources as Substitute for Mineral Fertilizers. Agronomy for Sustainable Development, 35, 667-678.

https://doi.org/10.1007/s13593-014-0251-4

[94] Nelissen, V., Rutting, T., Huygens, D., Staelens, J., Ruysschaert, G. and Boeckx, P. (2012) Maize Biochars Accelerate Short-Term Soil Nitrogen Dynamics in a Loamy Sand Soil. Soil Biology \& Biochemistry, 55, 20-27. https://doi.org/10.1016/j.soilbio.2012.05.019

[95] Mia, S., van Groenigen, J.W., van de Voorde, T.F.J., Oram, N.J., Bezemer, T.M., Mommer, L. and Jeffery, S. (2014) Biochar Application Rate Affects Biological Nitrogen Fixation in Red Clover Conditional on Potassium Availability. Agriculture Ecosystems \& Environment, 191, 83-91. https://doi.org/10.1016/j.agee.2014.03.011

[96] Gonzalez, M.E., Cea, M., Medina, J., Gonzalez, A., Diez, M.C., Cartes, P., Monreal, C. and Navia, R. (2015) Evaluation of Biodegradable Polymers as Encapsulating Agents for the Development of a Urea Controlled-Release Fertilizer Using Biochar as Support Material. Science of the Total Environment, 505, 446-453.

https://doi.org/10.1016/j.scitotenv.2014.10.014

[97] Houben, D., Sonnet, P. and Cornelis, J.T. (2014) Biochar from Miscanthus: A Potential Silicon Fertilizer. Plant and Soil, 374, 871-882.

https://doi.org/10.1007/s11104-013-1885-8

[98] Vassilev, N., Martos, E., Mendes, G., Martos, V. and Vassileva, M. (2013) Biochar of Animal Origin: A Sustainable Solution to the Global Problem of High-Grade Rock Phosphate Scarcity? Journal of the Science of Food and Agriculture, 93, 1799-1804. https://doi.org/10.1002/jsfa.6130

[99] Siebers, N., Godlinski, F. and Leinweber, P. (2014) Bone Char as Phosphorus Fertilizer Involved in Cadmium Immobilization in Lettuce, Wheat, and Potato Cropping. Journal of Plant Nutrition and Soil Science, 177, 75-83. https://doi.org/10.1002/jpln.201300113

[100] Dunisch, O., Lima, V.C., Seehann, G., Donath, J., Montoia, V.R. and Schwarz, T. (2007) Retention Properties of Wood Residues and Their Potential for Soil Amelioration. Wood Science and Technology, 41, 169-189.

https://doi.org/10.1007/s00226-006-0098-1

[101] Edelstein, D.M. and Tonjes, D.J. (2012) Modeling an Improvement in Phosphorus Utilization in Tropical Agriculture. Journal of Sustainable Agriculture, 36, 18-35. https://doi.org/10.1080/10440046.2011.627993

[102] Cui, H.J., Wang, M.K., Fu, M.L. and Ci, E. (2011) Enhancing Phosphorus Availability in Phosphorus-Fertilized Zones by Reducing Phosphate Adsorbed on Ferrihydrite Using Rice Straw-Derived Biochar. Journal of Soils and Sediments, 11, 1135-1141. https://doi.org/10.1007/s11368-011-0405-9

[103] Liu, X., Liu, M.D., Gao, Z.G. and Yang, D. (2013) Effect of Different Biochars on Yield and Yield Components of Wheat in Different Soils. Advances in Environmental Technologies, Pts 1-6, 726-731, 2665.

https://doi.org/10.4028/www.scientific.net/AMR.726-731.2665

[104] Glaser, B., Lehmann, J. and Zech, W. (2002) Ameliorating Physical and Chemical Properties of Highly Weathered Soils in the Tropics with Charcoal: A Review. Biology and Fertility of Soils, 35, 219-230. https://doi.org/10.1007/s00374-002-0466-4 
[105] Novak, J.M., Ippolito, J.A., Lentz, R.D., Spokas, K.A., Bolster, C.H., Sistani, K., Trippe, K.M., Phillips, C.L. and Johnson, M.G. (2016) Soil Health, Crop Productivity, Microbial Transport, and Mine Spoil Response to Biochars. Bioenergy Research, 9, 454-464. https://doi.org/10.1007/s12155-016-9720-8

[106] Yamato, M., Okimori, Y., Wibowo, I.F., Anshori, S. and Ogawa, M. (2006) Effects of the Application of Charred Bark of Acacia mangium on the Yield of Maize, Cowpea and Peanut, and Soil Chemical Properties in South Sumatra, Indonesia. Soil Science and Plant Nutrition, 52, 489-495. https://doi.org/10.1111/j.1747-0765.2006.00065.x

[107] Prendergast-Miller, M.T., Duvall, M. and Sohi, S.P. (2014) Biochar-Root Interactions Are Mediated by Biochar Nutrient Content and Impacts on Soil Nutrient Availability. European Journal of Soil Science, 65, 173-185.

https://doi.org/10.1111/ejss.12079

[108] Noguera, D., Rondon, M., Laossi, K.R., Hoyos, V., Lavelle, P., de Carvalho, M.H.C. and Barot, S. (2010) Contrasted Effect of Biochar and Earthworms on Rice Growth and Resource Allocation in Different Soils. Soil Biology \& Biochemistry, 42, 1017-1027. https://doi.org/10.1016/j.soilbio.2010.03.001

[109] Mukherjee, A. and Zimmerman, A.R. (2013) Organic Carbon and Nutrient Release from a Range of Laboratory-Produced Biochars and Biochar-Soil Mixtures. Geoderma, 193, 122-130. https://doi.org/10.1016/j.geoderma.2012.10.002

[110] Park, J.H., Choppala, G.K., Bolan, N.S., Chung, J.W. and Chuasavathi, T. (2011) Biochar Reduces the Bioavailability and Phytotoxicity of Heavy Metals. Plant and Soil, 348, 439-451. https://doi.org/10.1007/s11104-011-0948-y

[111] Lashari, M.S., Liu, Y.M., Li, L.Q., Pan, W.N., Fu, J.Y., Pan, G.X., Zheng, J.F., Zheng, J.W., Zhang, X.H. and Yu, X.Y. (2013) Effects of Amendment of Biochar-Manure Compost in Conjunction with Pyroligneous Solution on Soil Quality and Wheat Yield of a Salt-Stressed Cropland from Central China Great Plain. Field Crops Research, 144, 113-118. https://doi.org/10.1016/j.fcr.2012.11.015

[112] Major, J., Rondon, M., Molina, D., Riha, S.J. and Lehmann, J. (2010) Maize Yield and Nutrition during 4 Years after Biochar Application to a Colombian savanna Oxisol. Plant and Soil, 333, 117-128. https://doi.org/10.1007/s11104-010-0327-0

[113] Mehmood, K., Li, J.Y., Jiang, J., Masud, M.M. and Xu, R.K. (2017) Effect of Low Energy-Consuming Biochars in Combination with Nitrate Fertilizer on Soil Acidity Amelioration and Maize Growth. Journal of Soils and Sediments, 17, 790-799. https://doi.org/10.1007/s11368-015-1219-y

[114] Cornelissen, G., Rutherford, D.W., Arp, H.P.H., Dorsch, P., Kelly, C.N. and Rostad, C.E. (2013) Sorption of Pure $\mathrm{N}_{2} \mathrm{O}$ to Biochars and Other Organic and Inorganic Materials under Anhydrous Conditions. Environmental Science \& Technology, 47, 7704-7712. https://doi.org/10.1021/es400676q

[115] Obia, A., Mulder, J., Martinsen, V., Cornelissen, G. and Borresen, T. (2016) In Situ Effects of Biochar on Aggregation, Water Retention and Porosity in Light-Textured Tropical Soils. Soil \& Tillage Research, 155, 35-44.

https://doi.org/10.1016/j.still.2015.08.002

[116] Uzoma, K.C., Inoue, M., Andry, H., Fujimaki, H., Zahoor, A. and Nishihara, E. (2011) Effect of Cow Manure Biochar on Maize Productivity under Sandy Soil Condition. Soil Use and Management, 27, 205-212. https://doi.org/10.1111/j.1475-2743.2011.00340.x

[117] Zhang, H.H., Lin, K.D., Wang, H.L. and Gan, J. (2010) Effect of Pinus radiata Derived Biochars on Soil Sorption and Desorption of Phenanthrene. Environmental 
Pollution, 158, 2821-2825. https://doi.org/10.1016/j.envpol.2010.06.025

[118] Qin, X.B., Li, Y.E., Wang, H., Liu, C., Li, J.L., Wan, Y.F., Gao, Q.Z., Fan, F.L. and Liao, Y.L. (2016) Long-Term Effect of Biochar Application on Yield-Scaled Greenhouse Gas Emissions in a Rice Paddy Cropping System: A Four-Year Case Study in South China. Science of the Total Environment, 569, 1390-1401.

https://doi.org/10.1016/j.scitotenv.2016.06.222

[119] Wisnubroto, E., Hedley, M., Hina, K. and Camps-Arbestain, M. (2010) The Use of Biochar from Biosolids on Waitarere Sandy Soils: Effect on the Growth of Rye Grass. Proceedings of New Zealand Biochar Research Centre Workshop, Massey University, New Zealand, 10-11.

[120] Asai, H., Samson, B.K., Stephan, H.M., Songyikhangsuthor, K., Homma, K., Kiyono, Y., Inoue, Y., Shiraiwa, T. and Horie, T. (2009) Biochar Amendment Techniques for Upland Rice Production in Northern Laos 1. Soil Physical Properties, Leaf SPAD and Grain Yield. Field Crops Research, 111, 81-84.

https://doi.org/10.1016/j.fcr.2008.10.008

[121] Steiner, C., Teixeira, W.G., Lehmann, J., Nehls, T., de Macedo, J.L.V., Blum, W.E.H. and Zech, W. (2007) Long Term Effects of Manure, Charcoal and Mineral Fertilization on Crop Production and Fertility on a Highly Weathered Central Amazonian Upland Soil. Plant and Soil, 291, 275-290.

https://doi.org/10.1007/s11104-007-9193-9

[122] Blackwell, P., Krull, E., Butler, G., Herbert, A. and Solaiman, Z. (2010) Effect of Banded Biochar on Dryland Wheat Production and Fertiliser Use in South-Western Australia: An Agronomic and Economic Perspective. Australian Journal of Soil Research, 48, 531-545. https://doi.org/10.1071/SR10014

[123] Arif, M., Ali, K., Jan, M.T., Shah, Z., Jones, D.L. and Quilliam, R.S. (2016) Integration of Biochar with Animal Manure and Nitrogen for Improving Maize Yields and Soil Properties in Calcareous Semi-Arid Agroecosystems. Field Crops Research, 195, 28-35. https://doi.org/10.1016/j.fcr.2016.05.011

[124] Zhang, J.X., Zhang, Z.F., Shen, G.M., Wang, R., Gao, L., Kong, F.Y. and Zhang, J.G. (2016) Growth Performance, Nutrient Absorption of Tobacco and Soil Fertility after Straw Biochar Application. International Journal of Agriculture and Biology, 18, 983-989. https://doi.org/10.17957/IJAB/15.0197

[125] Li, F.Y., Cao, X.D., Zhao, L., Wang, J.F. and Ding, Z.L. (2014) Effects of Mineral Additives on Biochar Formation: Carbon Retention, Stability, and Properties. Environmental Science \& Technology, 48, 11211-11217. https://doi.org/10.1021/es501885n

[126] Chavez, A., Ramaswami, A., Nath, D., Guru, R. and Kumar, E. (2012) Implementing Trans-Boundary Infrastructure-Based Greenhouse Gas Accounting for Delhi, India Data Availability and Methods. Journal of Industrial Ecology, 16, 814-828. https://doi.org/10.1111/j.1530-9290.2012.00546.x

[127] He, T.Y., Meng, J., Chen, W.F., Liu, Z.Q., Cao, T., Cheng, X.Y., Huang, Y.W. and Yang, X. (2017) Effects of Biochar on Cadmium Accumulation in Rice and Cadmium Fractions of Soil: A Three-Year Pot Experiment. Bioresources, 12, 622-642. https://doi.org/10.15376/biores.12.1.622-642

[128] Cayuela, M.L., van Zwieten, L., Singh, B.P., Jeffery, S., Roig, A. and Sanchez-Monedero, M.A. (2014) Biochar's Role in Mitigating Soil Nitrous Oxide Emissions: A Review and Meta-Analysis. Agriculture Ecosystems \& Environment, 191, 5-16. https://doi.org/10.1016/j.agee.2013.10.009 
[129] van Zwieten, L., Kimber, S., Downie, A., Morris, S., Petty, S., Rust, J. and Chan, K.Y. (2010) A Glasshouse Study on the Interaction of Low Mineral Ash Biochar with Nitrogen in a Sandy Soil. Australian Journal of Soil Research, 48, 569-576. https://doi.org/10.1071/SR10003

[130] Jones, D.L., Murphy, D.V., Khalid, M., Ahmad, W., Edwards-Jones, G. and DeLuca, T.H. (2011) Short-Term Biochar-Induced Increase in Soil $\mathrm{CO}_{2}$ Release Is Both Biotically and Abiotically Mediated. Soil Biology \& Biochemistry, 43, 1723-1731. https://doi.org/10.1016/j.soilbio.2011.04.018

[131] Yanai, Y., Toyota, K. and Okazaki, M. (2007) Effects of Charcoal Addition on $\mathrm{N}_{2} \mathrm{O}$ Emissions from Soil Resulting from Rewetting Air-Dried Soil in Short-Term Laboratory Experiments. Soil Science and Plant Nutrition, 53, 181-188. https://doi.org/10.1111/j.1747-0765.2007.00123.x

[132] Rogovska, N., Laird, D., Cruse, R., Fleming, P., Parkin, T. and Meek, D. (2011) Impact of Biochar on Manure Carbon Stabilization and Greenhouse Gas Emissions. Soil Science Society of America Journal, 75, 871-879. https://doi.org/10.2136/sssaj2010.0270

[133] Feng, Y.Z., Xu, Y.P., Yu, Y.C., Xie, Z.B. and Lin, X.G. (2012) Mechanisms of Biochar Decreasing Methane Emission from Chinese Paddy Soils. Soil Biology \& Biochemistry, 46, 80-88. https://doi.org/10.1016/j.soilbio.2011.11.016

[134] Case, S.D.C., McNamara, N.P., Reay, D.S. and Whitaker, J. (2014) Can Biochar Reduce Soil Greenhouse Gas Emissions from a Miscanthus Bioenergy Crop? Global Change Biology Bioenergy, 6, 76-89. https://doi.org/10.1111/gcbb.12052

[135] Quin, P., Joseph, S., Husson, O., Donne, S., Mitchell, D., Munroe, P., Phelan, D., Cowie, A. and Van Zwieten, L. (2015) Lowering $\mathrm{N}_{2} \mathrm{O}$ Emissions from Soils Using Eucalypt Biochar: The Importance of Redox Reactions. Scientific Reports, 5, Article No. 16773. https://doi.org/10.1038/srep16773

[136] Zhang, A.F., Liu, Y.M., Pan, G.X., Hussain, Q., Li, L.Q., Zheng, J.W. and Zhang, X.H. (2012) Effect of Biochar Amendment on Maize Yield and Greenhouse Gas Emissions from a Soil Organic Carbon Poor Calcareous Loamy Soil from Central China Plain. Plant and Soil, 351, 263-275. https://doi.org/10.1007/s11104-011-0957-x

[137] Scheer, C., Grace, P.R., Rowlings, D.W., Kimber, S. and Van Zwieten, L. (2011) Effect of Biochar Amendment on the Soil-Atmosphere Exchange of Greenhouse Gases from an Intensive Subtropical Pasture in Northern New South Wales, Australia. Plant and Soil, 345, 47-58. https://doi.org/10.1007/s11104-011-0759-1

[138] Spokas, K.A., Koskinen, W.C., Baker, J.M. and Reicosky, D.C. (2009) Impacts of Woodchip Biochar Additions on Greenhouse Gas Production and Sorption/Degradation of Two Herbicides in a Minnesota Soil. Chemosphere, 77, 574-581. https://doi.org/10.1016/j.chemosphere.2009.06.053

[139] Kimetu, J.M. and Lehmann, J. (2010) Stability and Stabilisation of Biochar and Green Manure in Soil with Different Organic Carbon Contents. Australian Journal of Soil Research, 48, 577-585. https://doi.org/10.1071/SR10036

[140] Lu, W.W., Ding, W.X., Zhang, J.H., Li, Y., Luo, J.F., Bolan, N. and Xie, Z.B. (2014) Biochar Suppressed the Decomposition of Organic Carbon in a Cultivated Sandy Loam Soil: A Negative Priming Effect. Soil Biology \& Biochemistry, 76, 12-21. https://doi.org/10.1016/j.soilbio.2014.04.029

[141] Karhu, K., Mattila, T., Bergstrom, I. and Regina, K. (2011) Biochar Addition to Agricultural Soil Increased $\mathrm{CH}_{4}$ Uptake and Water Holding Capacity: Results from 
a Short-Term Pilot Field Study. Agriculture Ecosystems \& Environment, 140, 309-313. https://doi.org/10.1016/j.agee.2010.12.005

[142] Hui, D., Yu, C.L., Deng, Q., Saini, P., Collins, K. and De Koff, J. (2018) Weak Effects of Biochar and Nitrogen Fertilization on Switchgrass Photosynthesis, Biomass, and Soil Respiration. Agriculture, 8, 12. https://doi.org/10.3390/agriculture8090143

[143] Singh, B.P. and Cowie, A.L. (2014) Long-Term Influence of Biochar on Native Organic Carbon Mineralisation in a Low-Carbon Clayey Soil. Scientific Reports, 4, Article No. 3687. https://doi.org/10.1038/srep03687

[144] Trivedi, P., Anderson, I.C. and Singh, B.K. (2013) Microbial Modulators of Soil Carbon Storage: Integrating Genomic and Metabolic Knowledge for Global Prediction. Trends in Microbiology, 21, 641-651. https://doi.org/10.1016/j.tim.2013.09.005

[145] Cross, A. and Sohi, S.P. (2011) The Priming Potential of Biochar Products in Relation to Labile Carbon Contents and Soil Organic Matter Status. Soil Biology \& Biochemistry, 43, 2127-2134. https://doi.org/10.1016/j.soilbio.2011.06.016

[146] Zimmerman, A.R., Gao, B. and Ahn, M.Y. (2011) Positive and Negative Carbon Mineralization Priming Effects among a Variety of Biochar-Amended Soils. Soil Biology \& Biochemistry, 43, 1169-1179. https://doi.org/10.1016/j.soilbio.2011.02.005

[147] Bruun, S. and Luxhoi, J. (2008) Is Biochar Production Really Carbon-Negative? Environmental Science \& Technology, 42, 1388-1388.

https://doi.org/10.1021/es087078g

[148] Cheng, C.H., Lehmann, J., Thies, J.E., Burton, S.D. and Engelhard, M.H. (2006) Oxidation of Black Carbon by Biotic and Abiotic Processes. Organic Geochemistry, 37, 1477-1488. https://doi.org/10.1016/j.orggeochem.2006.06.022

[149] Cai, Z., Xing, G., Yan, X., Xu, H., Tsuruta, H., Yagi, K. and Minami, K. (1997) Methane and Nitrous Oxide Emissions from Rice Paddy Fields as Affected by Nitrogen Fertilisers and Water Management. Plant and Soil, 196, 7-14.

https://doi.org/10.1023/A:1004263405020

[150] Cai, Z., Tsuruta, H. and Minami, K. (2000) Methane Emission from Rice Fields in China: Measurements and Influencing Factors. Journal of Geophysical Research: Atmospheres, 105, 17231-17242. https://doi.org/10.1029/2000JD900014

[151] Xiong, Z.-Q., et al. (2007) Nitrous Oxide and Methane Emissions as Affected by Water, Soil and Nitrogen. Pedosphere, 17, 146-155.

https://doi.org/10.1016/S1002-0160(07)60020-4

[152] Van Zwieten, L., Singh, B., Joseph, S., Kimber, S., Cowie, A. and Chan, K.Y. (2009) Biochar and Emissions of Non- $\mathrm{CO}_{2}$ Greenhouse Gases from Soil. Biochar for Environmental Management: Science and Technology, 1, 227-250.

[153] Zhang, A.F., Cui, L.Q., Pan, G.X., Li, L.Q., Hussain, Q., Zhang, X.H., Zheng, J.W. and Crowley, D. (2010) Effect of Biochar Amendment on Yield and Methane and Nitrous Oxide Emissions from a Rice Paddy from Tai Lake Plain, China. Agriculture Ecosystems \& Environment, 139, 469-475.

https://doi.org/10.1016/j.agee.2010.09.003

[154] Knoblauch, C., Maarifat, A.A., Pfeiffer, E.M. and Haefele, S.M. (2011) Degradability of Black Carbon and Its Impact on Trace Gas Fluxes and Carbon Turnover in Paddy Soils. Soil Biology \& Biochemistry, 43, 1768-1778.

https://doi.org/10.1016/j.soilbio.2010.07.012

[155] Khan, S., Chao, C., Waqas, M., Arp, H.P.H. and Zhu, Y.G. (2013) Sewage Sludge Biochar Influence upon Rice (Oryza sativa L) Yield, Metal Bioaccumulation and Greenhouse Gas Emissions from Acidic Paddy Soil. Environmental Science \& 
Technology, 47, 8624-8632. https://doi.org/10.1021/es400554x

[156] Zhao, L., Zheng, W. and Cao, X.D. (2014) Distribution and Evolution of Organic Matter Phases during Biochar Formation and Their Importance in Carbon Loss and Pore Structure. Chemical Engineering Journal, 250, 240-247. https://doi.org/10.1016/j.cej.2014.04.053

[157] Rondon, M., Ramirez, J. and Lehmann, J. (2006) Charcoal Additions Reduce Net Emissions of Greenhouse Gases to the Atmosphere. Proceedings of the $3 r d$ USDA Symposium on Greenhouse Gases and Carbon Sequestration in Agriculture and Forestry, Philadelphia, July 9-15 2006, 21-24.

[158] Rondon, M.A., Molina, D., Hurtado, M., Ramirez, J., Lehmann, J., Major, J. and Amezquita, E. (2016) Enhancing the Productivity of Crops and Grasses While Reducing Greenhouse Gas Emissions through Bio-Char Amendments to Unfertile Tropical Soils. Proceedings of 18 th World Congress of Soil Science, Philadelphia, July 9-15 2006, 9-15.

[159] Yu, L.Q., Tang, J., Zhang, R.D., Wu, Q.H. and Gong, M.M. (2013) Effects of Biochar Application on Soil Methane Emission at Different Soil Moisture Levels. Biology and Fertility of Soils, 49, 119-128. https://doi.org/10.1007/s00374-012-0703-4

[160] Dong, D., Yang, M., Wang, C., Wang, H.L., Li, Y., Luo, J.F. and Wu, W.X. (2013) Responses of Methane Emissions and Rice Yield to Applications of Biochar and Straw in a Paddy Field. Journal of Soils and Sediments, 13, 1450-1460.

https://doi.org/10.1007/s11368-013-0732-0

[161] Liu, X., Zhang, Y., Li, Z.F., Feng, R. and Zhang, Y.Z. (2014) Characterization of Corncob-Derived Biochar and Pyrolysis Kinetics in Comparison with Corn Stalk and Sawdust. Bioresource Technology, 170, 76-82. https://doi.org/10.1016/j.biortech.2014.07.077

[162] Jia, J.X., Li, B., Chen, Z.Z., Xie, Z.B. and Xiong, Z.Q. (2012) Effects of Biochar Application on Vegetable Production and Emissions of $\mathrm{N}_{2} \mathrm{O}$ and CH4. Soil Science and Plant Nutrition, 58, 503-509. https://doi.org/10.1080/00380768.2012.686436

[163] Johnson-Beebout, S.E., Angeles, O.R., Alberto, M.C.R. and Buresh, R.J. (2009) Simultaneous Minimization of Nitrous Oxide and Methane Emission from Rice Paddy Soils Is Improbable Due to Redox Potential Changes with Depth in a Greenhouse Experiment without Plants. Geoderma, 149, 45-53. https://doi.org/10.1016/j.geoderma.2008.11.012

[164] Wang, J.Y., Pan, X.J., Liu, Y.L., Zhang, X.L. and Xiong, Z.Q. (2012) Effects of Biochar Amendment in Two Soils on Greenhouse Gas Emissions and Crop Production. Plant and Soil, 360, 287-298. https://doi.org/10.1007/s11104-012-1250-3

[165] Yagi, K. and Minami, K. (1990) Effect of Organic Matter Application on Methane Emission from Some Japanese Paddy Fields. Soil Science and Plant Nutrition, 36, 599-610. https://doi.org/10.1080/00380768.1990.10416797

[166] Kögel-Knabner, I., Amelung, W., Cao, Z., Fiedler, S., Frenzel, P., Jahn, R., Kalbitz, K., Kölbl, A. and Schloter, M. (2010) Biogeochemistry of Paddy Soils. Geoderma, 157, 1-14. https://doi.org/10.1016/j.geoderma.2010.03.009

[167] Cayuela, M.L., Jeffery, S. and van Zwieten, L. (2015) The Molar H:Corg Ratio of Biochar Is a Key Factor in Mitigating $\mathrm{N}_{2} \mathrm{O}$ Emissions from Soil. Agriculture Ecosystems \& Environment, 202, 135-138. https://doi.org/10.1016/j.agee.2014.12.015

[168] Felber, R., Leifeld, J., Horak, J. and Neftel, A. (2014) Nitrous Oxide Emission Reduction with Greenwaste Biochar: Comparison of Laboratory and Field Experiments. European Journal of Soil Science, 65, 128-138. 
https://doi.org/10.1111/ejss.12093

[169] Van Zwieten, L., Singh, B.P., Kimber, S.W.L., Murphy, D.V., Macdonald, L.M., Rust, J. and Morris, S. (2014) An Incubation Study Investigating the Mechanisms That Impact $\mathrm{N}_{2} \mathrm{O}$ Flux from Soil Following Biochar Application. Agriculture Ecosystems \& Environment, 191, 53-62. https://doi.org/10.1016/j.agee.2014.02.030

[170] Clough, T.J., Bertram, J.E., Ray, J.L., Condron, L.M., O’Callaghan, M., Sherlock, R.R. and Wells, N.S. (2010) Unweathered Wood Biochar Impact on Nitrous Oxide Emissions from a Bovine-Urine-Amended Pasture Soil. Soil Science Society of America Journal, 74, 852-860. https://doi.org/10.2136/sssaj2009.0185

[171] Hale, S.E., Lehmann, J., Rutherford, D., Zimmerman, A.R., Bachmann, R.T., Shitumbanuma, V., O’Toole, A., Sundqvist, K.L., Arp, H.P.H. and Cornelissen, G. (2012) Quantifying the Total and Bioavailable Polycyclic Aromatic Hydrocarbons and Dioxins in Biochars. Environmental Science \& Technology, 46, 2830-2838. https://doi.org/10.1021/es203984k

[172] Taghizadeh-Toosi, A., Clough, T.J., Condron, L.M., Sherlock, R.R., Anderson, C.R. and Craigie, R.A. (2011) Biochar Incorporation into Pasture Soil Suppresses in Situ Nitrous Oxide Emissions from Ruminant Urine Patches. Journal of Environmental Quality, 40, 468-476. https://doi.org/10.2134/jeq2010.0419

[173] Lorenz, K. and Lal, R. (2014) Biochar Application to Soil for Climate Change Mitigation by Soil Organic Carbon Sequestration. Journal of Plant Nutrition and Soil Science, 177, 651-670. https://doi.org/10.1002/jpln.201400058

[174] Luo, X.X., Wang, L.Y., Liu, G.C., Wang, X., Wang, Z.Y. and Zheng, H. (2016) Effects of Biochar on Carbon Mineralization of Coastal Wetland Soils in the Yellow River Delta, China. Ecological Engineering, 94, 329-336.

https://doi.org/10.1016/j.ecoleng.2016.06.004

[175] Sun, L.Y., Li, L., Chen, Z.Z., Wang, J.Y. and Xiong, Z.Q. (2014) Combined Effects of Nitrogen Deposition and Biochar Application on Emissions of $\mathrm{N}_{2} \mathrm{O}, \mathrm{CO}_{2}$ and $\mathrm{NH}_{3}$ from Agricultural and Forest Soils. Soil Science and Plant Nutrition, 60, 254-265. https://doi.org/10.1080/00380768.2014.885386

[176] Rittl, T.F., Novotny, E.H., Balieiro, F.C., Hoffland, E., Alves, B.J.R. and Kuyper, T.W. (2015) Negative Priming of Native Soil Organic Carbon Mineralization by Oilseed Biochars of Contrasting Quality. European Journal of Soil Science, 66, 714-721. https://doi.org/10.1111/ejss.12257

[177] Riaz, M., Roohi, M., Arif, M.S., Hussain, Q., Yasmeen, T., Shahzad, T., Shahzad, S.M., Muhammad, H.F., Arif, M. and Khalid, M. (2017) Corncob-Derived Biochar Decelerates Mineralization of Native and Added Organic Matter (AOM) in Organic Matter Depleted Alkaline Soil. Geoderma, 294, 19-28.

https://doi.org/10.1016/j.geoderma.2017.02.002

[178] Jeffery, S., Meinders, M.B.J., Stoof, C.R., Bezemer, T.M., van de Voorde, T.F.J., Mommer, L. and van Groenigen, J.W. (2015) Biochar Application Does Not Improve the Soil Hydrological Function of a Sandy Soil. Geoderma, 251, 47-54. https://doi.org/10.1016/j.geoderma.2015.03.022

[179] Sagrilo, E., Jeffery, S., Hoffland, E. and Kuyper, T.W. (2015) Emission of $\mathrm{CO}_{2}$ from Biochar-Amended Soils and Implications for Soil Organic Carbon. Global Change Biology Bioenergy, 7, 1294-1304. https://doi.org/10.1111/gcbb.12234

[180] Zheng, H., Wang, X., Luo, X.X., Wang, Z.Y. and Xing, B.S. (2018) Biochar-Induced Negative Carbon Mineralization Priming Effects in a Coastal Wetland Soil: Roles of Soil Aggregation and Microbial Modulation. Science of the Total Environment, 610, 951-960. https://doi.org/10.1016/j.scitotenv.2017.08.166 
[181] Soinne, H., Hovi, J., Tammeorg, P. and Turtola, E. (2014) Effect of Biochar on Phosphorus Sorption and Clay Soil Aggregate Stability. Geoderma, 219, 162-167. https://doi.org/10.1016/j.geoderma.2013.12.022

[182] Archanjo, B.S., Baptista, D.L., Sena, L.A., Cancado, L.G., Falcao, N.P.S., Jorio, A. and Achete, C.A. (2015) Nanoscale Mapping of Carbon Oxidation in Pyrogenic Black Carbon from Ancient Amazonian Anthrosols. Environmental ScienceProcesses \& Impacts, 17, 775-779. https://doi.org/10.1039/C4EM00590B

[183] Maestrini, B., Herrmann, A.M., Nannipieri, P., Schmidt, M.W.I. and Abiven, S. (2014) Ryegrass-Derived Pyrogenic Organic Matter Changes Organic Carbon and Nitrogen Mineralization in a Temperate Forest Soil. Soil Biology \& Biochemistry, 69, 291-301. https://doi.org/10.1016/j.soilbio.2013.11.013

[184] Jeffery, S., Memelink, I., Hodgson, E., Jones, S., van de Voorde, T.F.J., Bezemer, T.M., Mommer, L. and van Groenigen, J.W. (2017) Initial Biochar Effects on Plant Productivity Derive from N Fertilization. Plant and Soil, 415, 435-448.

https://doi.org/10.1007/s11104-016-3171-Z

[185] DeLuca, T.H. and Sala, A. (2006) Frequent Fire Alters Nitrogen Transformations in Ponderosa Pine Stands of the Inland Northwest. Ecology, 87, 2511-2522.

https://doi.org/10.1890/0012-9658(2006)87[2511:FFANTI]2.0.CO;2

[186] Elad, Y., David, D.R., Harel, Y.M., Borenshtein, M., Ben Kalifa, H., Silber, A. and Graber, E.R. (2010) Induction of Systemic Resistance in Plants by Biochar, a Soil-Applied Carbon Sequestering Agent. Phytopathology, 100, 913-921. https://doi.org/10.1094/PHYTO-100-9-0913

[187] Jiang, J., Xu, R.K., Jiang, T.Y. and Li, Z. (2012) Immobilization of $\mathrm{Cu}(\mathrm{II}), \mathrm{Pb}$ (II) and Cd(II) by the Addition of Rice Straw Derived Biochar to a Simulated Polluted Ultisol. Journal of Hazardous Materials, 229, 145-150. https://doi.org/10.1016/j.jhazmat.2012.05.086

[188] Ezawa, T., Smith, S.E. and Smith, F.A. (2002) P Metabolism and Transport in AM Fungi. Plant and Soil, 244, 221-230. https://doi.org/10.1023/A:1020258325010

[189] Fang, G.D., Liu, C., Gao, J., Dionysiou, D.D. and Zhou, D.M. (2015) Manipulation of Persistent Free Radicals in Biochar to Activate Persulfate for Contaminant Degradation. Environmental Science \& Technology, 49, 5645-5653. https://doi.org/10.1021/es5061512

[190] Kappler, A., Wuestner, M.L., Ruecker, A., Harter, J., Halama, M. and Behrens, S. (2014) Biochar as an Electron Shuttle between Bacteria and Fe(III) Minerals. Environmental Science \& Technology Letters, 1, 339-344. https://doi.org/10.1021/ez5002209

[191] Lone, A.H., Najar, G.R., Ganie, M.A., Sofi, J.A. and Ali, T. (2015) Biochar for Sustainable Soil Health: A Review of Prospects and Concerns. Pedosphere, 25, 639-653. https://doi.org/10.1016/S1002-0160(15)30045-X 